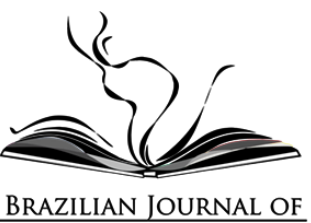

\title{
IIRSA, cosiplan e a atuação brasileira na consolidação da integração de infraestrutura na américa do sul
}

\author{
IIRSA, COSIPLAN Y LA ACTUACIÓN BRASILEÑA EN LA CONSOLIDACIÓN DE
} LA INTEGRACIÓN DE INFRAESTRUCTURA EN AMÉRICA DEL SUR

IIRSA, COSIPLAN AND THE BRAZILIAN PERFORMANCE IN THE CONSOLIDATION OF INFRASTRUCTURE INTEGRATION IN SOUTH AMERICA

\author{
Jéssica Maria Grassi ${ }^{\top}$ \\ Universidade Federal de Santa Catarina, Brasil \\ Ana Karolina Morais Silva² (iD \\ Universidade Federal da Integração Latino-Americana, Brasil \\ Lucas Kerr Oliveira ${ }^{3}$ (iD) \\ Universidade Federal da Integração Latino-Americana, Brasil
}

Resumo: No presente artigo visamos discutir a atuação brasileira nos projetos da IIRSA e do Cosiplan, considerando as diferentes interpretações acerca do papel que o Brasil desempenhou neste processo. Inicialmente, são desenvolvidos os conceitos de subimperialismo, liderança regional e potência regional e, a partir desta discussão teórica-conceitual, o artigo explora a formação e evolução da IIRSA e do Cosiplan apresentando a atuação brasileira em ambos. Através desta revisão bibliográfica, combinada com a análise dos dados do investimento realizado nas iniciativas de integração de infraestrutura no mesmo período, buscamos testar a hipótese segundo a qual a participação brasileira na integração de infraestrutura sul-americana, durante os governos de Fernando Henrique Cardoso, Luiz Inácio Lula da Silva e Dilma Rousseff, se deu sob uma lógica subimperialista. Conclui-se que a tese do subimperialismo brasileiro não se sustenta através da revisão bibliográfica e dos dados de investimentos, os quais demonstram que o Brasil buscou liderar o processo de integração na

\footnotetext{
' Doutoranda no Programa de Pós-Graduação em Relações Internacionais (PPGRI) na Universidade Federal de Santa Catarina (UFSC) e Bolsista CAPES. E-mail: jessica.grassi@posgrad.ufsc.br

${ }^{2}$ Mestranda no Programa de Pós-Graduação em Integração Contemporânea da América Latina (PPG-ICAL) da Universidade Federal da Integração Latino-Americana (UNILA) e Bolsista de Demanda Social (DS/UNILA). E-mail: ana.morais@aluno.unila.edu.br

3 Professor do Programa de Pós-graduação em Integração Contemporânea da América Latina (PPG-ICAL), da Universidade Federal da Integração Latino-Americana (UNILA). Doutor em Ciência Política pela Universidade Federal do Rio Grande do Sul (UFRGS). E-mail: lucas.oliveira@unila.edu.br.
} 
região em uma ação coerente com os seus interesses geopolíticos, visando melhorar sua inserção internacional através da cooperação e da consolidação da integração do bloco regional sul-americano.

Palavras-chave: Subimperialismo; Liderança Regional; América do Sul; Infraestrutura; IIRSA.

Resumen: En este artículo pretendemos discutir el desempeño brasileño en los proyectos de IIRSA y Cosiplan, considerando las diferentes interpretaciones sobre el papel que Brasil jugó en este proceso. Inicialmente, se desarrollan los conceptos de subimperialismo, liderazgo regional y potencia regional y, en base a esta discusión teórico-conceptual, el artículo explora la formación y evolución de IIRSA y Cosiplan, presentando el desempeño brasileño dentro de ambos. A través de esta revisión bibliográfica, combinada con el análisis de los datos de inversión realizados en las iniciativas de integración de infraestructura en el mismo período, colocamos en prueba la hipótesis según la cual la participación brasileña en la integración de la infraestructura sudamericana, durante los gobiernos de Fernando Henrique Cardoso, Luiz Inácio Lula da Silva y Dilma Rousseff, se desarrolló bajo una lógica subimperialista. Se concluye que tal hipótesis del subimperialismo brasileño no se sustenta a través de la revisión bibliográfica y de los datos de inversión, que demuestran que Brasil buscó liderar el proceso de integración en la región en una acción coherente con sus intereses geopolíticos, con el objetivo de mejorar su inserción internacional a través de la cooperación y la consolidación de la integración del bloque regional sudamericano.

Palabras-clave: Subimperialismo; Liderazgo Regional; Sudamérica; Infraestructura; IIRSA.

Abstract: Through this article we aim to discuss the Brazilian performance in the projects of IIRSA and Cosiplan, considering the different interpretations about the role that Brazil played in this process. Initially, the concepts of sub-imperialism, regional leadership and regional power are developed and, based on this theoretical-conceptual discussion, the article explores the formation and evolution of IIRSA and Cosiplan presenting the Brazilian performance in the scope of both. Through this bibliographic review, combined with the analysis of investment data made in infrastructure integration initiatives in the same period, we test the hypothesis according to which participation Brazilian integration of South American infrastructure, during the governments of Fernando Henrique Cardoso, Luiz Inácio Lula da Silva and Dilma Rousseff, it took place under a sub-imperialist logic. It follows that the hypothesis of Brazilian sub-imperialism is not supported by bibliographic review and investment data, which demonstrate that Brazil sought to lead the integration process in the region in an action consistent with its geopolitical interests, aiming 
to improve its international insertion through cooperation and the consolidation of the South American regional bloc integration.

Keywords: Sub-imperialism; Regional Leadership; South America; Infrastructure; IIRSA.

\section{INTRODUÇÃO}

A Iniciativa para a Integração da Infraestrutura Regional Sul-Americana (IIRSA) se desenvolveu a partir da proposta aprovada na I Reunião de Presidentes Sul-Americanos, realizada em Brasília, entre 31 de agosto e $1^{\circ}$ de setembro de 2000, com o objetivo de "impulsionar a integração e modernização da infraestrutura física de transportes, energia e comunicações ${ }^{4}$, sob uma perspectiva regionalista do continente Sul-Americano" (COMUNICADO DE BRASÍLIA, 2000, s. p.).

Tendo sido inicialmente proposta pelo governo brasileiro durante a Presidência de Fernando Henrique Cardoso, foi oficializada em 2002 e se desenvolveu a partir de um formato intergovernamental com reuniões multilaterais entre os Presidentes da região. Mais tarde, os projetos da IIRSA foram agregados à agenda da então nascente União das Nações Sul-Americanas (Unasul), no âmbito do Conselho Sul-Americano de Infraestrutura e Planejamento (Cosiplan). No que diz respeito à atuação brasileira, há diversas discussões sobre o papel que o país exerceu na iniciativa e os seus interesses e projetos.

Desse modo, com este artigo, busca-se compreender a atuação brasileira nos projetos da IIRSA/Cosiplan, dando ênfase ao período

\footnotetext{
${ }^{4}$ No setor dos transportes, a prioridade era facilitar o trânsito de pessoas, cargas e veículos através de rodovias, ferrovias, rotas fluviais e marítimas, que também dinamizaria o comércio e os investimentos na região. No setor energético, buscava-se, essencialmente, integrar e complementar os recursos da região (especialmente dos recursos minerais, como petróleo e gás natural), assim como ampliar a interconexão elétrica. Já na área de telecomunicações, o objetivo seria estabelecer uma rede que permitisse a cooperação visando suprir as demandas de logística da informação da região (HONÓRIO, 2013).
} 
compreendido entre sua criação, durante o governo do Presidentes Fernando Henrique Cardoso (1995-2002), e o governo Luiz Inácio Lula da Silva (2003-2010) e Dilma Rousseff (2011-2016). Devido à multiplicidade de discussões acerca do papel que o Brasil desempenha na região apontadas na primeira seção do artigo -, optou-se por enfatizar o que diz respeito à tese do subimperialismo brasileiro na América do Sul, de modo a ressaltar e aprofundar esse importante debate e verificar a sustentação da hipótese proposta.

Para a elaboração deste trabalho, contamos com uma revisão bibliográfica de especialistas nas temáticas relacionadas, uma revisão de fontes primárias, como documentos e dados da IIRSA e relativos à integração sul-americana, assim como dados relativos ao financiamento dos projetos, empregando o método hipotético dedutivo para desenvolver a pesquisa.

Na primeira seção do texto, realiza-se uma revisão bibliográfica dos conceitos de subimperialismo, liderança regional e potência regional, aplicados ao caso brasileiro e às relações entre o Brasil e seus vizinhos, visando investigar as visões e as possibilidades referentes à atuação do país na América do Sul. Em sua segunda seção, busca-se analisar a criação e o desenvolvimento da IIRSA/Cosiplan, identificando os propósitos e a atuação brasileira na organização.

Revisitando os debates teóricos e conceituais da primeira seção, são apresentados e analisados dados e argumentos referentes ao papel do Brasil nos projetos da iniciativa. Desse modo, na terceira e última seção do trabalho, desenvolvemos uma análise acerca do financiamento dos projetos da IIRSA/Cosiplan, utilizando dados da própria instituição, com vistas a aprofundar o debate sobre o papel do financiamento brasileiro através do Banco Nacional de Desenvolvimento Econômico e Social (BNDES). 
Conclui-se, por fim, que o papel desempenhado pelo Brasil nos projetos de infraestrutura não corrobora com interpretações que afirmam que o país seja subimperialista, mas sim faz parte de um projeto geopolítico brasileiro. Tal projeto é resultante de um longo ciclo no qual o país buscou se projetar como líder regional, visando tornar-se uma potência regional, arcando minimamente com custos da construção da infraestrutura integrada na região, para inserir-se internacionalmente de forma mais autônoma, sem abdicar da construção e/ou manutenção da liderança na região sul-americana.

\section{O BRASIL EM MEIO AO DEBATE TEÓRICO: UM PAÍS SUBIMPERIALISTA OU UMA POTÊNCIA EM BUSCA DE LIDERANÇA REGIONAL?}

Nesta seção, busca-se desenvolver os conceitos de subimperialismo, liderança regional e potência regional para analisar a participação brasileira nos processos de integração da infraestrutura regional sul-americana nos escopos da IIRSA e do Cosiplan. Tal revisão teórica embasará a discussão da hipótese do subimperialismo brasileiro, segundo a qual o Brasil seria um país subimperialista, subordinado ao imperialismo ${ }^{5}$ central, utilizando os processos de integração para consolidar sua exportação de capitais na América do Sul.

A partir do debate existente sobre o problema do desenvolvimento capitalista nos países latino-americanos, desenvolveu-se, no seio da Comissão Econômica para a América Latina e o Caribe (CEPAL), a Teoria da Dependência. Esta é compreendida por diversos autores como um corpo heterogêneo em seu referencial teórico básico, sendo composta por

\footnotetext{
${ }^{5}$ No marco do imperialismo tradicional, uma referência clássica para o debate do imperialismo é a obra de Lênin, "O Imperialismo, Fase Superior do Capitalismo", de 1916. O pensador revolucionário definiu o imperialismo como uma fase do capitalismo, ao contrário da maior parte dos pensadores do início do século XX que definiam o imperialismo como uma política externa dos Estados. Sua análise dá prioridade ao papel do capital financeiro e dos monopólios no capitalismo (LÊNIN, 1916). Entre os autores que também se destacam ao trabalhar sobre o conceito de imperialismo estão Nicolai Bukharin e Rosa Luxemburgo. Já no marco das análises contemporâneas, destacam-se Samir Amim, Ellen Wood, Alex Callinicos e Atilio Boron.
} 
diversos autores cujas abordagens metodológicas variam. A Teoria da Dependência se consolidou a partir da década de 1960, em um período em que pensadores latino-americanos buscavam caminhos alternativos ao imposto pelo sistema capitalista aos países da região.

Já a Teoria Marxista da Dependência (TMD), a partir da década de 1970, buscou superar tanto o nacional desenvolvimentismo da CEPAL quanto o etapismo revolucionário típico dos Partidos Comunistas latino-americanos do período. Os autores dessa escola, como Theotônio dos Santos, Vânia Bambirra, André Gunder Frank e Ruy Mauro Marini, criaram um corpo teórico crítico pautado nas especificidades históricas do desenvolvimento capitalista na América Latina (SEABRA, 2019).

Cabe ressaltar que o período histórico no qual a Teoria Marxista da Dependência se desenvolveu coincide com o período da Ditadura Militar brasileira. Nesse período, entre 1964 e 1985, intercalaram-se no poder governos com alinhamentos pragmáticos ${ }^{6}$ e alinhamentos automáticos $^{7}$ aos Estados Unidos (PECEQUILO, 2011). Além disso, o pensamento geopolítico brasileiro desde Mário Travassos ${ }^{8}$ até o período ditatorial identificava a América do Sul como área de influência direta do Brasil, considerando que a região era destinada ao exercício e expansão do poder brasileiro, competindo com a Argentina pelo domínio desse território. Ainda, a região era compreendida como uma área de instabilidade e possibilidades de conflitos, principalmente no entorno fronteiriço (CERVO, 2008; COSTA, 2008; JAEGER, 2018; GRASSI, 2019a).

Ademais, ao longo dos anos de 1970 ocorreram as tratativas para a construção da Hidrelétrica de Itaipu entre Brasil e Paraguai - as quais foram iniciadas na década anterior -, sendo este marcado como um

\footnotetext{
${ }^{6}$ Não significaria a subordinação dos interesses brasileiros aos norte-americanos, nem resultaria a perda do espaço na América do Sul, mas há a troca de favores, "visando à obtenção de vantagens e à valorização do papel estratégico do país no subcontinente" (PECEQUILO, 2011, p. 19).

7 Supõe que a adesão às políticas norte-americanas resultaria em concessões. Para a autora, o automatismo é associado, muitas vezes, ao sentimento de euforia brasileira diante de manifestações positivas norte-americanas (PECEQUILO, 2011).

${ }^{8}$ Mário Travassos (1891 - 1973) foi um militar brasileiro, autor de "Projeção Continental do Brasil" (1935), um dos primeiros estudos sobre geopolítica feitos no Brasil.
} 
período de ápice das rivalidades entre Argentina e Brasil (SARAIVA, 2012; GRASSI, 2019a e 2019b). Desde então, muito tem mudado na região e nas relações entre os países, como será mencionado nas seções seguintes.

Segundo Ruy Mauro Marini, sob o regime militar, a burguesia industrial brasileira, impossibilitada de expandir o mercado interno brasileiro, optou pela tentativa de compensar essa limitação através da incorporação de mercados que já estivessem formados em países vizinhos, como, por exemplo, o mercado uruguaio (MARINI, 1974).

A partir das discussões acerca da burguesia brasileira, Marini desenvolveu, nos anos 1970, o conceito de subimperialismo, o qual define como "a forma que assume a economia dependente ao chegar na etapa dos monopólios e do capital financeiro" (MARINI, 1977, p. 18, tradução nossa). No prefácio de sua obra "Subdesenvolvimento e Revolução", afirma que o subimperialismo pode ser compreendido:

a) a partir da reestruturação do sistema capitalista global, que é derivado da nova divisão internacional do trabalho, e;

b) a partir das leis próprias da economia dependente, essencialmente: a superexploração do trabalho, o divórcio entre as fases do ciclo de capital, a monopolização extrema em favor da indústria suntuária, a integração de capital nacional ao capital estrangeiro ou, o que é o mesmo, a integração de sistemas (MARINI, 1974, p. XIII, tradução nossa).

Para Marini, o subimperialismo só é possível quando: (i) há conformação de uma composição orgânica média do capital; e (ii) há o exercício relativamente autônomo de uma política expansionista, a qual gera maior integração da economia subimperialista ao sistema produtivo imperialista, porém, de forma subordinada à hegemonia do imperialismo global. Assim, o autor classifica o Brasil como o único país em toda a América Latina a expressar plenamente o fenômeno subimperialista. Todavia, o subimperialismo brasileiro, apesar de possuir certo grau de autonomia e iniciativa, está subordinado ao imperialismo estadunidense. (MARINI, 1977). 
Partindo da teoria desenvolvida por Marini, Luce (2007) propõe que a atuação hegemônica ${ }^{9}$ na região por parte do governo Lula impregnou sua política para a integração regional com um caráter subimperialista, desenvolvendo-se na esfera consensual, sendo um novo subimperialismo, o social-liberal. Desse modo, a atuação do Brasil buscaria atender aos interesses da burguesia nacional, a qual estaria, segundo o autor, integrada ao imperialismo dominante (LUCE, 2007).

Nessa perspectiva, Fontes (2009) argumenta que o Brasil opera como uma plataforma subalterna dos capitais multinacionais presentes no país, que o utilizam para chegar à região sul-americana, levando a uma extensa reconfiguração do panorama sociopolítico do Brasil na contemporaneidade. Ademais, a autora alerta, entre outros fatores, sobre o papel do Banco Nacional de Desenvolvimento Econômico e Social (BNDES) para a consolidação do Brasil como uma plataforma dos capitais financeiros de potências imperialistas, afirmando que o banco atua na América do Sul com "substantivos aportes, direcionando algumas privatizações, favorecendo certos grupos" (FONTES, 2009, p. 235).

Ainda, Andrade (2015) e Lima (2018) afirmam que a participação dos capitais brasileiros na IIRSA/Cosiplan, através dos investimentos do BNDES na iniciativa, caracteriza o subimperialismo brasileiro. Isto porque a IIRSA é utilizada como um instrumento de política de hegemonia regional e compõe a cooperação antagônica entre o subimperialismo brasileiro e o imperialismo estadunidense, ao mesmo tempo que os capitais do BNDES contribuem para que a composição orgânica média do capital seja conformada, estabelecendo, assim, o subimperialismo como padrão de reprodução do capital.

\footnotetext{
9 Tendo em vista o recorte teórico proposto neste artigo, não se trouxe a discussão sobre um papel de hegemonia regional, outro termo relacionado ao Brasil e sua atuação na região. Entretanto, ressalta-se que a hegemonia mundial, conforme o conceito empregado por Arrighi (2006, p. 27), se refere "à capacidade de um Estado exercer funções de liderança e governo sobre um sistema de nações soberanas". Ademais, a potência hegemônica deve combinar coerção e consentimento e possuir a capacidade de universalizar seus interesses próprios como os interesses gerais dos atores que compõem o sistema internacional (ARRIGHI, 2006). Para Mearsheimer (2007), que parte de uma perspectiva realista do conceito de hegemonia, um Estado que busque estabelecer-se como hegemonia regional precisa ampliar a lacuna de poder entre si e seus vizinhos para evitar que outros Estados da sua região tenham os meios para ameaçá-lo ou mesmo organizar uma possível coalizão contra-balançante.
} 
Como contraponto ao argumento do subimperialismo brasileiro, os conceitos de liderança regional e potência regional também são comumente atribuídos à atuação do Brasil no contexto da América do Sul. Lima (2013) propõe que a liderança regional deve ser entendida como a capacidade de influenciar os resultados, e não de influenciar a terceiros. Padula (2010) aponta quatro formas de se exercer a liderança política e econômica regional:

(i) Uma liderança expansiva e assimétrica, concentrando ganhos políticos e econômicos no líder em detrimento do desempenho político e econômico dos demais países. (ii) Uma liderança em que a expansão do líder favoreça a expansão econômica e política dos demais países, mas que ainda assim, em última instância, concentre ganhos políticos e econômicos no líder, não combatendo assimetrias pré-existentes. (iii) Uma liderança em que a expansão do líder favoreça a expansão econômica e política dos demais países e do conjunto, mas que ainda trabalhe para manter sua posição privilegiada em termos de concentração regional de poderes político e econômico; assim, podendo até combater em grande medida as assimetrias estruturais pré-existentes entre os países da região e o líder, não visa comprometer a hierarquia regional estabelecida. (iv) Uma liderança cooperativa, na qual a expansão do líder impulsiona ganhos políticos e econômicos recíprocos dos países e do conjunto, reduzindo as assimetrias pré-existentes, na medida do possível (PADULA, 2010, p. 79).

Sobre a projeção de poder e a liderança brasileira na região, Lima (2013) defende ser necessário considerar os indicadores tradicionais para medir as capacidades dos países, como PIB e população. Fiori (2011) também traz variáveis importantes para analisar o papel de liderança regional, destacando a necessidade de vontade estratégica consistente e permanente, a coordenação estreita entre as agências responsáveis pela política externa do país, a capacidade social e estatal de construir consensos e a capacidade de planejar e implementar ações conjuntas. Partindo disso, poderia ser afirmado que o Brasil possuía as capacidades para projetar-se regionalmente como líder do processo de integração do bloco sul-americano.

Apesar de não existirem estudos comprovando o quanto uma suposta liderança brasileira foi aceita a nível regional, Lima (2013) aponta 
que os poucos estudos existentes demonstram uma ambiguidade latente nas opiniões de analistas e lideranças políticas no que se refere a este tema. Se, por um lado, a atuação brasileira na América do Sul sofre duras críticas, acusada de imperialista ou com intentos hegemônicos, por outro, esta também é criticada por aqueles que sugerem que o país não contribui suficientemente para o benefício da região (LIMA, 2013).

A sua vez, uma potência regional pode ser definida como um Estado que articula sua pretensão de liderança em uma região econômica, política e ideacionalmente delimitada, que tem grande influência nos assuntos regionais e que dispõe dos recursos materiais (militar, econômico, demográfico), organizacionais (políticos) e ideológicos para projetar seu poder regionalmente (NOLTE, 2010, p. 983).

Deve ser um Estado econômica, política e culturalmente interconectado com a região; que influencia na delimitação geopolítica e na construção política e econômica da região; que exerce influência nas estruturas de governança regional; que define e articula a identidade e o projeto comum da região; que proporciona e se esforça pelo bem coletivo; que define ou tem importante papel na definição da agenda de segurança; que tem sua liderança respeitada e reconhecida pelos demais países; que integra fóruns e instituições inter-regionais e globais, agindo não apenas pelos próprios interesses, mas representando também a região (NOLTE, 2010, p. 983).

Para que um Estado se constitua como uma potência regional, Gratius (2007) define que este precisa: fazer parte de uma região definida; aspirar à liderança regional; influenciar a construção regional política e geoestrategicamente; dispor de recursos materiais, organizacionais e ideológicos necessários ao projeto de poder regional; ter relações de interdependência a nível regional nas esferas política, econômica e cultural; ter grande influência nos assuntos regionais; ser reconhecido 
como líder pelos países da região; atuar como o representante ou porta-voz da região em foros internacionais.

Analisando a capacidade militar brasileira, o potencial demográfico e geográfico do país, bem como os recursos econômicos dos quais o Brasil dispõe, Gratius (2007) considera que o Brasil cumpre com todos os recursos quantificáveis necessários para que exerça o papel de potência regional, e até mesmo de potência mundial. Afirma, ainda, que o Brasil é o único país da América do Sul que possui esses recursos. Contudo, a autora considera que não está claro se o país possui a influência ou o reconhecimento dos países vizinhos, ambos necessários para que um país seja uma potência regional, além do fato do Brasil possuir problemas internos estruturais que operam como obstáculos para que o país assuma a posição de potência regional, mesmo que possua boa parte de todos os recursos necessários (GRATIUS, 2007).

Moniz Bandeira (2008) propõe que, para ser uma potência (regional ou mundial), um país necessita de significativa extensão territorial, poder econômico e poder militar. Tais recursos seriam necessários para que um país possa se expressar na política internacional de forma independente e influenciar a ação de outros Estados.

Há, inclusive, discussões que, por considerarem que o Brasil não atende todos os requisitos de uma potência regional, apesar de ser o país com mais condições de assumir esse papel na região, ao analisarem a atuação brasileira na América do Sul durante a primeira década do século XXI, propõem a designação de potência regional emergente ou, em alguns casos, como potência emergente (GRATIUS, 2007; FLEMES; SARAIVA, 2014).

Em suma, nota-se que a atuação brasileira na América do Sul pode ser compreendida a partir de diferentes prismas. Dessa forma, ao exemplificar esse fato, tratou-se aqui da tese do subimperialismo brasileiro, bem como das perspectivas de liderança e potência regionais. Assim, a partir dessa análise conceitual, poderá ser examinada a atuação brasileira 
no que diz respeito à IIRSA/Cosiplan, bem como ser testada a definição de subimperialismo para este caso. Contudo, antes disso, será necessário compreender brevemente a formação da IIRSA e do Cosiplan, dentro do contexto da Unasul, o que será feito na próxima seção.

\section{A GEOPOLÍTICA BRASILEIRA NA AMÉRICA DO SUL: A IIRSA/COSIPLAN E A INTEGRAÇÃO DE INFRAESTRUTURA NA AMÉRICA DO SUL (2000-2016)}

Por incorporar novos temas à agenda da integração regional, a I Reunião de Presidentes da América do Sul, ocorrida em Brasília, em setembro de 2000, durante o governo de Fernando Henrique Cardoso, pode ser considerada o grande ponto de inflexão do regionalismo sul-americano. Nessa ocasião, os doze chefes de Estado concluíram a necessidade da união regional para promover o desenvolvimento e a inserção global, acordando em impulsionar a integração política, social e econômica da América do Sul. A partir disso, em 2002, formalizou-se a Iniciativa para a Integração da Infraestrutura Regional Sul-Americana (IIRSA), a primeira iniciativa de integração regional no subcontinente que contou com a participação dos 12 países sul-americanos (PADULA, 2010; HONÓRIO, 2013).

A partir dos ganhos obtidos desde então, na III Reunião de Presidentes da América do Sul, realizada em 2004, em Cusco, no Peru, os líderes dos países discutiram novos delineamentos para a integração regional, como a redução das assimetrias entre os países e maior coordenação política. A partir disso, surgiu a proposta da Comunidade das Nações Sul-Americanas (CASA/CNS) ${ }^{10}$. No entanto, em 2007, os presidentes resolveram substituir a CASA, e, em 2008, aprovaram o Tratado Constitutivo que criou a União das Nações Sul-Americanas (Unasul).

\footnotetext{
${ }^{10}$ No Brasil costuma-se utilizar a sigla CASA, no entanto, nos demais países sul-americanos, também se utiliza a sigla CNS para a Comunidade de Nações Sul-Americanas.
} 
Partindo disso, a IIRSA foi considerada o embrião do processo que culminou na criação da Unasul, pelas perspectivas, objetivos, propostas e logros no diálogo conjunto mantido entre os presidentes sul-americanos desde os anos 2000. Contudo, a partir das críticas endereçadas à iniciativa quanto à lacuna política em seu processo, os países avançaram em direção a um modelo mais político de integração, sendo, por isso, a infraestrutura tratada, posteriormente, como apenas um dos eixos ou pilares da Unasul.

No âmbito da Unasul, criou-se o Conselho Sul-Americano de Infraestrutura e Planejamento (Cosiplan), em 2009, o qual incorporou a IIRSA, no intento por superar a falta de conexão da iniciativa com os esquemas de integração regional, munindo-os, assim, de um guarda-chuva institucional. Desde sua criação, inúmeros projetos foram financiados, sendo que, no final de 2016, o portfólio da IIRSA contava com o total de 581 projetos de integração, somando um investimento estimado de US\$191,42 bilhões (COSIPLAN, 2016).

A IIRSA foi pensada como um projeto de integração geopolítica ou como uma integração dos mercados regionais, com vistas a reduzir as assimetrias regionais e angariar melhorias nos âmbitos econômico-comerciais e mesmo sociais. Apesar dos objetivos e da proposta oficial da IIRSA, várias críticas, como o subimperialismo brasileiro (LUCE, 2007; CECEÑA, 2009), foram direcionadas à iniciativa.

Há muitas discussões sobre a busca do Estado brasileiro por um padrão de relações regionais que se baseie na projeção política e econômica do país como um meio para a internacionalização das empresas nacionais, sendo a região um espaço privilegiado para o adensamento dos negócios (SENNES, 2010; SPEKTOR, 2010). Para Sennes (2010, p. 124):

É possível identificar uma agenda de interesses regional do Brasil, mas longe de ser uma agenda integracionista e ampla, ela é seletiva, focada na preservação da capacidade decisória doméstica e na manutenção dos instrumentos de fomento com caráter nacional e voltada a alavancar projetos e interesses brasileiros. 
A este ponto de vista, Spektor (2010) acrescenta que três proposições marcariam o pensamento brasileiro sobre a região: a primeira é a de que o Brasil pode exercer influência nas relações internacionais sem que isso necessariamente o torne uma potência regional; a segunda é a de que a região pode proteger a "autonomia nacional" em um mundo globalizado; e a terceira, segundo a qual a região pode servir para aumentar o poder, o prestígio e a influência nacional brasileira. A partir destas três proposições, segundo o autor, estariam evidenciadas algumas ambiguidades da atitude brasileira em relação à América do Sul.

Nessa direção, Castro (2012) ressalta a importância de se levar em consideração a complementaridade dos Eixos Nacionais de Integração e Desenvolvimento" e os Eixos de Integração e Desenvolvimento presentes na IIRSA. A infraestrutura buscada pelo Brasil teria, portanto, como objetivo principal conectá-lo com o litoral do pacífico, devido à importância do transporte e escoamento dos produtos nacionais (CASTRO, 2012).

Os Planos de Aceleração do Crescimento (PAC I e II) ${ }^{12}$ e a IIRSA assumem a mesma orientação de integração competitiva, adotando um modelo de modernização com base em mega projetos de investimentos. Construídos na mesma perspectiva, os projetos do PAC e da IIRSA articulam-se e parecem coordenados e complementares, como se observa na consulta feita aos dados oficiais das instâncias sul-americanas de planejamento (CASTRO, 2012, p.45-46).

Entretanto, é fundamental pontuar também que a IIRSA representaria a possibilidade dos países da região se tornarem mais competitivos no mercado internacional (CASTRO, 2012) e usufruírem de condições mais vantajosas na competição internacional e inter-regional (MORAIS SILVA; KERR OLIVEIRA, 2019). Ressalta-se também que, além de impactar positivamente o comércio, a integração da infraestrutura auxilia na integração das áreas periféricas do continente e das áreas fronteiriças,

\footnotetext{
"Segundo Castro (2012, p. 48) "Os Eixos Nacionais de Integração e Desenvolvimento constituíram a matriz de planejamento e intervenção", pressupondo "uma visão geográfica de domínio e controle dos territórios". Esses Eixos estiveram presentes no Plano Brasil em Ação (1996-1999), no Avança Brasil (2000-2003) e nos Planos Plurianuais de 1996-1999, 2000-2003 e 2004-2007, que revelam as prioridades espaciais do Estado (CASTRO, 2012). ${ }^{12}$ Criado em 2007, o PAC tinha por objetivo promover a retomada do planejamento e da execução de grandes obras de infraestrutura social, urbana, logística e energética do Brasil. Em 2011, a segunda fase do PAC aprimorou a fase anterior, com mais recursos e parcerias (MINISTÉRIO DO PLANEJAMENTO, 2020).
} 
aumentando a atuação do Estado nessas regiões, de modo a garantir maior segurança e capacidade de defesa, bem como gerar o desenvolvimento socioeconômico (JAEGER, 2014).

A melhoria da infraestrutura regional é sublinhada como crucial para a defesa da América do Sul, uma vez que, desde os anos 1970, há no cenário internacional o acirramento de disputas por mercados e pelo controle de recursos estratégicos de longo prazo, especialmente recursos energéticos, gerando disputas hegemônicas em todas as regiões do mundo, contexto no qual a América do Sul está indissociavelmente inserida (FIORI, 2008; KERR OLIVEIRA; MARQUES, 2015).

Nesse sentido, sobre a atuação brasileira no processo integracionista sul-americano, desde o segundo mandato do Presidente Fernando Henrique Cardoso passou a se pontuar o entendimento por parte do país da interdependência e da vinculação entre a prosperidade do Brasil e a dos seus vizinhos. Dessa maneira, no final do governo de Cardoso desenvolveu-se o pensamento de que o Brasil deveria assumir de fato seu papel de liderança na América do Sul e nos governos Lula isso foi reiterado com o Brasil declarando a prioridade da América do Sul e destacando sua disposição de exercer a liderança no subcontinente (MONIZ BANDEIRA, 2008; LIMA, 2013).

Sobre o contexto regional do princípio dos anos 2000, Moniz Bandeira afirma:

O Brasil estava a exercer de fato a liderança da América do Sul, aceita consensualmente pelos demais governos da região, dado seu enorme peso econômico, político e estratégico, sem pretensões de hegemonia, respeitando as particularidades de cada povo. E a Segunda Reunião de Presidentes da América do Sul realizou-se em Guayaquil, Equador, entre 26 e 27 de julho de 2002, quando foi aprovado o "Consenso de Guayaquil sobre Integração, Segurança e Infraestrutura para o Desenvolvimento", manifestando o propósito de construir "um futuro de convivência fecunda e pacífica, de permanente cooperação" e declarando "a América do Sul como Zona de Paz e Cooperação" (MONIZ BANDEIRA, 2008, p. 19). 
Assim, a integração regional foi posta como uma das principais estratégias políticas e econômicas dos governos Lula e Dilma (AMORIM, 2009). Guimarães (2008, p. 68-69) salienta que "a solidariedade nos esforços de desenvolvimento e de integração é uma ideia central na estratégia brasileira na América do Sul". Do mesmo modo, Moniz Bandeira (2008, p. 28) também destaca essa ideia ao apontar que o Brasil, durante o governo Lula, teve a integração regional como um objetivo estratégico, porque o país havia compreendido que "a união dos demais países da América do Sul com o Brasil [...] em uma comunidade econômica e política, conformaria uma grande potência, com enorme peso no cenário mundial."

No período de análise deste estudo, o Brasil buscou desenvolver relativa autonomia em relação aos Estados Unidos (VISENTINI, 2008), bem como procurou fugir da tendência do principal elemento do regionalismo aberto na região, a proliferação de tratados de livre-comércio assinados com os Estados Unidos. A partir disso, com uma postura baseada em um cálculo estratégico, buscou fortalecer seu papel de liderança na América do Sul, almejando desenvolver sua atuação no cenário internacional, visando, assim, reduzir a ingerência externa na região e aumentar a confiança dos vizinhos sobre sua projeção internacional (PAZ, 2015).

Sobre isso, ainda, Guimarães (2008, p. 68) reitera a importância da redução das assimetrias de natureza econômica e social no contexto de um processo integracionista, sendo necessário, para isso, programas específicos e ambiciosos. Nessa perspectiva, haveria a necessidade de "um processo de transferência de renda sob a forma de investimentos entre os Estados participantes", como o que estava sendo desenvolvido naquele período com o Fundo para a Convergência Estrutural do Mercado Comum do Sul (Mercosul), o Focem.

Guimarães também relembra que o Presidente Lula mencionou diversas vezes a relevância da generosidade dos países maiores e mais 
desenvolvidos para o êxito da integração na América do Sul. Isso significa que "o Brasil deve estar disposto a conceder tratamento mais vantajoso sem reciprocidade a todos os seus vizinhos, em especial àqueles de menor desenvolvimento relativo, aos países mediterrâneos e aos países de menor PIB per capita." (GUIMARÃES, 2008, p. 68).

Quando se trata da integração em infraestrutura na região, observou-se que uma das maiores dificuldades para conduzir os projetos é a dificuldade de os países sul-americanos acessarem o crédito internacional para investimentos, devido às limitações ao endividamento externo e à inacessibilidade aos instrumentos de garantia. Pela prioridade dada pelos países sul-americanos ao pagamento da dívida interna e externa, estes países têm considerável dificuldade para elevarem a sua poupança interna e, consequentemente, dependem do mercado internacional de capitais para investirem em infraestrutura (GUIMARÃES, 2008).

Desta forma, o Brasil atuou ao longo dos primeiros anos do século XXI para fortalecer instituições financeiras como a Cooperação Andina de Fomento (CAF), visando promover os investimentos em infraestrutura na região, bem como incentivou a proposta de um Banco do Sul, em uma clara tentativa por ampliar a autonomia financeira sul-americana (GUIMARÃES, 2008).

Além disso, por ser um dos poucos, senão o único país da região, que dispunha de um forte banco de desenvolvimento no período em análise - BNDES -, o Brasil buscou fazer uma diferença qualitativa nos investimentos na infraestrutura da América do Sul (GUIMARÃES, 2008; SENHORAS, 2008). Isso porque os ativos do Banco, em 2008, eram "de US\$ 87 bilhões, maiores que os do Banco Interamericano de Desenvolvimento - BID (US\$ 66 bilhões)" e este poderia "emprestar recursos para a execução de obras de infraestrutura em condições competitivas com as do mercado internacional e sem condicionar tais empréstimos a 
'compromissos' de política externa ou à execução de 'reformas' econômicas internas" (GUIMARÃES, 2008, p. 67).

Sobre a atuação na IIRSA, também pode-se observar, na Carteira de Projetos do Cosiplan de 2016, que o Brasil foi o segundo país em número total de projetos, atrás da Argentina. No entanto, o valor total de investimento foi maior. Em porcentagem, o Brasil possuía 13,82\% dos projetos, e 44,83\% dos investimentos. Isso pode ser visualizado na tabela 1 a seguir.

Tabela 1 - Projetos concluídos por país (em bilhões de US\$)

\begin{tabular}{cccccc}
\hline País & $\begin{array}{c}\mathbf{N}^{\circ} \text { total de } \\
\text { projetos }\end{array}$ & $\begin{array}{c}\mathbf{N}^{\circ} \text { de } \\
\text { projetos } \\
\text { concluídos }\end{array}$ & \% projetos & $\begin{array}{c}\text { Quantidade } \\
\text { de } \\
\text { investiment } \\
\mathbf{0}\end{array}$ & $\begin{array}{c}\text { \% } \\
\text { investiment } \\
\text { o }\end{array}$ \\
\hline Argentina & 178 & 23 & 15,4 & 6,215 & 21,0 \\
\hline Bolívia & 53 & 5 & 3,4 & 0,017 & 0,1 \\
\hline Brasil & 94 & 28 & 18,81 & 13,296 & 44,8 \\
\hline Chile & 74 & 22 & 14,8 & 2,065 & 7,0 \\
\hline Colômbia & 33 & 14 & 9,4 & 0,726 & 2,4 \\
\hline Equador & 40 & 16 & 10,7 & 0,813 & 2,7 \\
\hline Guiana & 8 & 2 & 1,3 & 0,010 & 0,0 \\
\hline Paraguai & 66 & 11 & 7,4 & 1,994 & 6,7 \\
\hline Peru & 72 & 19 & 12,8 & 3,914 & 13,2 \\
\hline Uruguai & 42 & 7 & 4,7 & 0,481 & 1,6 \\
\hline Venezuela & 20 & 2 & 1,3 & 0,125 & 0,4 \\
\hline
\end{tabular}

Fonte: Cosiplan (2016, p. 36). Tradução nossa.

Cabe salientar a importância de um "agente integrador", que possua a capacidade e a vontade de assumir os custos materiais e simbólicos, para alavancar o processo de integração regional (WEXELL SEVERO, 2015). Nessa perspectiva,

analisando os dados, o Brasil concentra 51\% do PIB, $49 \%$ da população e $48 \%$ do território da América do Sul. Mesmo não sendo o país com maior PIB per capita, possui fronteiras com nove dos onze vizinhos e contribui com mais da metade da produção industrial da região. Além disso, conta com o BNDES, a terceira maior instituição de fomento do mundo. Pareceria não existir dúvidas, sobretudo por parte dos demais países sul-americanos, de que a viabilidade do processo de integração aumentaria consideravelmente se o Brasil assumisse a postura de líder (WEXELL SEVERO, 2015, p. 203-204). 
Guimarães (2008) afirma que a estratégia brasileira de integração possui três elementos centrais: (i) financiar obras de infraestrutura nos países sul-americanos e chegar a fornecer créditos a empresas desses países, sob as mesmas condições às quais os créditos são concedidos a empresas brasileiras, visando o crescimento e o desenvolvimento dos países vizinhos, pela importância que os mercados destes países possuem para as exportações brasileiras; (ii) reduzir as assimetrias econômicas e sociais da região por meio do processo de transferência de renda através de entos entre os Estados sul-americanos (como ocorre no processo de integração europeu); (iii) a generosidade dos países maiores e mais desenvolvidos, oferecendo tratamento diferenciado em diversas áreas a todos os países da América do Sul que fazem parte do processo de integração regional, sem exigência de reciprocidade.

Nesse sentido, o caráter de liderança brasileira, principalmente no que diz respeito à integração de infraestrutura, acabou por se confundir a com um movimento de expansão territorial. No entanto, para Senhoras (2008, p. 201-202), essa liderança está relacionada às debilidades regionais e à "própria evolução singular do capitalismo periférico", mas que abriu possibilidades "de uma política menos dependente dos EUA, com grandes implicações estratégicas e consequências históricas importantes para a região".

Ainda assim, essa liderança regional encontrou obstáculos tanto no nível doméstico, como os relativos a questões orçamentárias e às próprias assimetrias internas, quanto regionais, como os temores e críticas dos países vizinhos à possibilidade de uma atuação expansionista. Por outro lado, também houve críticas devido à falta de um papel mais significativo de paymaster ${ }^{13}$ e, a nível internacional, devido aos limites impostos pela potência norte-americana (SENHORAS, 2008; CARVALHO; GONÇALVES, 2016).

\footnotetext{
${ }^{13}$ Expressão do inglês, utilizada para identificar o principal país financiador do processo integracionista.
} 
Essas limitações foram mais visíveis durante o governo de Dilma Rousseff. Apesar da manutenção das intenções e propostas dos governos anteriores, os esforços foram relativamente inferiores, com um menor ativismo em assuntos regionais, agravados pelo cenário externo desfavorável, a crise econômica e política que começou a se apresentar e pelas fragilidades anteriores não resolvidas (CARVALHO; GONÇALVES, 2016; GRASSI, 2019b). Dessa forma, conforme Carvalho e Gonçalves:

\begin{abstract}
O país conservou os recursos materiais que permitiram defini-lo como potência regional, mas, no campo da liderança, percebem-se claros sinais de enfraquecimento no que tange tanto às modalidades consensual, cooperativa, empreendedora, como estrutural e distributiva e normativa e intelectual. A fragilidade doméstica e a reversão de condições externas tiveram reflexos diretos para as ações brasileiras direcionadas à promoção dos seus interesses no âmbito da região e as condições para o exercício da liderança ficaram comprometidas. Consequentemente, o país não conseguiu se posicionar como elo integrador regional e liderar a construção de um espaço geopolítico autônomo como na gestão anterior (CARVALHO; GONÇALVES, 2016, p. 243).
\end{abstract}

Em suma, destaca-se que, no período analisado nesta seção, as relações com o entorno geográfico foram marcadas pelo diálogo, pelo soft power $^{14}$, pela busca do desenvolvimento econômico e social, da autonomia política, da estabilidade e segurança regional e, desse modo, da consolidação da integração regional.

As mudanças no governo brasileiro, a partir da ruptura institucional de 2016, que pôs fim ao segundo governo Dilma Rousseff, e a eleição (em 2018) de um governo ideologicamente de extrema-direita, defensor do alinhamento automático e subalterno aos EUA, provocou um direcionamento radical da política externa brasileira, com uma ruptura, ao menos no plano do discurso e das políticas governamentais de curto prazo, do secular projeto de liderança regional e de consolidação da posição do Brasil como potência regional, que vinham sendo construídos lentamente

\footnotetext{
${ }^{14}$ Do inglês, poder brando. Conceito proposto por Nye Jr. (2009, p. 76-77), refere-se à "capacidade de estabelecer a pauta política de maneira a expressar as preferências dos outros [...], tende a estar associada com recursos de poder intangíveis como a cultura, a ideologia e as instituições [...]."
} 
como parte da Grande Estratégia brasileira (AMORIM, 2016; KERR OLIVEIRA et al, 2016).

A partir dessas visões gerais acerca da IIRSA e do seu papel no subcontinente, na próxima seção, propõe-se examinar a atuação brasileira dentro da iniciativa, buscando demonstrar a forma com que a inserção brasileira na América do Sul pode ser compreendida sob o ponto de vista da integração infraestrutural.

\section{A CARTEIRA DE PROJETOS DA IIRSA/COSIPLAN E SUAS FONTES DE FINANCIAMENTO: O PAPEL DO BRASIL E DO BNDES}

A conjuntura regional do período de surgimento da IIRSA favorecia a abertura comercial, razão pela qual o Investimento Estrangeiro Direto (IED) 15 e o capital privado foram considerados como fatores essenciais para o funcionamento e operacionalização da iniciativa. Assim, a iniciativa foi conduzida pelo Comitê de Coordenação Técnica (CCT), formado pelo BID, o CAF e o Fundo Financeiro para o Desenvolvimento da Bacia do Prata (FONPLATA) (PADULA, 2010).

O BID foi criado em 1959 pelos países-membros da Organização dos Estados Americanos (OEA) e todos os países-membros da UNASUL também compõem o BID. Entre os objetivos da instituição estão a redução da pobreza e das desigualdades sociais, a promoção da cooperação e integração regionais, bem como do desenvolvimento através da iniciativa privada (BID, 2020).

Sediado em Caracas, o CAF foi fundado em 1970, formado por 19 países, dos quais 17 são parte da América Latina, além de Espanha e Portugal, e por 14 bancos privados da região. Atua promovendo o desenvolvimento e a integração regional na América Latina, através de

\footnotetext{
${ }^{15}$ O Investimento Estrangeiro Direto (IED) é a movimentação de capitais internacionais para investimento, quando empresas ou indivíduos no exterior criam operações em outro país, de acordo com a Agência Brasileira de Promoção de Exportações e Investimentos: http://www.apexbrasil.com.br/o-que-e-ied.
} 
recursos para a realização de vários serviços financeiros, de alto valor agregado, para clientes dos setores público e privado (CAF, 2020).

O FONPLATA é uma entidade financeira ligada ao Tratado da Bacia do Prata (1969-1970) destinada a prestar apoio técnico e financeiro à realização de estudos, projetos, programas, obras e iniciativas que promovam o desenvolvimento harmônico e a integração física dos países membros da Bacia do Prata: Argentina, Bolívia, Brasil, Paraguai e Uruguai (FONPLATA, 2020).

Quando abordamos o tema do financiamento das obras da IIRSA/Cosiplan, a atuação do BNDES no financiamento de projetos de infraestrutura na região também é um tema em debate. O BNDES foi e é considerado o protagonista da internacionalização do capital brasileiro, como financiador de longo prazo para que as empresas brasileiras pudessem realizar grandes obras na região. Além disso, o Banco colaborou para as fusões e aquisições de empresas em outros países ao facilitar o acesso aos fundos de investimento. No entanto, não se tem precisão sobre os financiamentos dos projetos, devido à pobreza dos dados disponibilizados pelo Banco pela alegação de sigilo bancário, bem como as limitações do site da IIRSA (PAZ, 2015; BRAGA, 2013).

Em 2002, o estatuto do BNDES foi alterado para apoiar as operações das empresas brasileiras voltadas ao exterior, especialmente aos projetos de integração regional. Assim, o Banco passou a atuar com mais desenvoltura na IIRSA, apoiando com somas milionárias as grandes empresas que têm interferido com suas obras no reordenamento territorial da América do Sul. [...] $\bigcirc$ discurso pautado numa política de cooperação técnica e na instalação de uma infraestrutura mais moderna permitiu o avanço das oportunidades de negócios para empresas brasileiras, como a Petrobrás, o Banco do Brasil, a Odebrecht, a Camargo Corrêa a Gerdau, a Votorantim, a Vale do Rio Doce, o JBS-Friboi, a Companhia Siderúrgica Nacional, a Andrade Gutierrez, entre outras, e os grupos internacionais a elas associados. [...] Nesse cenário de competitividade, o BNDES operou por meio da transferência de um volume expressivo de recursos públicos, através de créditos subsidiados, para os grandes grupos econômicos e empresas que atuavam preferencialmente nos setores de commodities (BRAGA, 2013, p. 13). 
A iniciativa se encontra, muitas vezes, atrelada à discussão da expansão das empresas brasileiras de construção civil na região através do BNDES, bem como ligada à questão do aumento da presença brasileira nos países da região através de produtos e de empresas. Essa visão é a de que houve um perfil hegemônico na atuação brasileira, uma vez que os projetos da IIRSA seriam a expressão da natureza subimperialista do Brasil (HONÓRIO, 2013).

Sob este argumento, Paz (2015) defendia que a atuação do BNDES na região sul-americana haveria beneficiado a classe empresarial brasileira através da liberação de crédito subsidiado. Assim, os interesses político-econômicos brasileiros teriam se realizado, utilizando a América do Sul como plataforma para a projeção geopolítica do Brasil, uma vez que as obras de infraestrutura na região serviram para ampliar a presença econômica e a influência política do país na região.

Em relação à participação das empresas brasileiras de construção civil e engenharia na IIRSA, o governo brasileiro reconhece que estas são superiores competitivamente às demais da América do Sul e reforça as condições para que elas sejam beneficiadas nesse sentido. Assim, para Luce (2007), a atuação das grandes empresas brasileiras, apoiadas pelo BNDES, e as políticas de integração do governo Lula não cumpriram o objetivo enunciado de enfrentar as assimetrias, ao contrário, aprofundaram o intercâmbio desigual e a divisão regional desigual do trabalho.

Além disso, os impactos das obras financiadas pelo BNDES receberam inúmeras denúncias, alegando-se que "as promessas de uma integração regional pautada na justiça social e no respeito ao meio ambiente não se concretizou", pelo contrário, se acentuaram "as assimetrias socioespaciais a partir da construção de gasodutos, oleodutos, hidrelétricas e estradas, que seguem os interesses das grandes empresas e não das comunidades locais" (BRAGA, 2013, p. 17). 
Segue-se agora a uma breve análise da Carteira de Projetos do Cosiplan, documento que compila informações referentes aos projetos desenvolvidos no seio da iniciativa. Segundo a Carteira de 2016, 61\% de todo o montante financeiro destinado às obras da instituição foi oriundo do setor público, enquanto o setor privado representava $19 \%$ dos investimentos totais e as iniciativas público-privadas representavam 20\%. Ainda, 13\% dos investimentos esperados não possuíam uma fonte designada. Quanto ao número total de projetos existentes, 82\% contavam com financiamento público, seguido por 12\% de projetos financiados pelo setor privado e apenas 6\% financiados pelo setor público-privado (COSIPLAN, 2016).

No mesmo ano, os projetos de transporte eram majoritariamente financiados pelo setor público, já as obras de infraestrutura energética contavam com uma participação semelhante do setor público e das iniciativas público-privadas e, por fim, o setor de comunicações era completamente financiado pelo setor público (COSIPLAN, 2016). A tabela 2, a seguir, detalha as fontes de financiamento da Carteira de Projetos do Cosiplan, em bilhões de dólares, até o mês de agosto de 2016. 
Tabela 2 - Fontes de Financiamento (em bilhões de US\$)

\begin{tabular}{cccc}
\hline $\begin{array}{c}\text { Fonte de } \\
\text { financiamento }\end{array}$ & $\mathbf{N}^{\mathbf{0}}$ de projetos & $\begin{array}{c}\text { Investimento } \\
\text { estimado }\end{array}$ & $\begin{array}{c}\text { Investimento } \\
\text { executado }\end{array}$ \\
\hline Tesouro nacional & 354 & 72,368 & 14,435 \\
\hline Privados & 88 & 48,728 & 5,574 \\
\hline Por definir & 78 & 42,312 & 0,170 \\
\hline BID & 39 & 4,629 & 1,150 \\
\hline CAF & 30 & 2,855 & 0,795 \\
\hline $\begin{array}{c}\text { Tesouro } \\
\text { estadual/provincial }\end{array}$ & 18 & 1,875 & 0,200 \\
\hline Binacional & 13 & 9,647 & 1,408 \\
\hline FOCEM & 10 & 0,819 & 0,419 \\
\hline Vários & 8 & 1,939 & 1,342 \\
\hline FONPLATA & 6 & 0,298 & 0,0 \\
\hline Por definir (público) & 6 & 0,403 & 0,0 \\
\hline Por definir (privado) & 5 & 1,149 & 0,388 \\
\hline Bancos privados & 4 & 0,108 & 0,0 \\
\hline Banco Mundial & 4 & 0,172 & 0,068 \\
\hline União Europeia & 4 & 0,179 & 0,075 \\
\hline JBIC & 3 & 0,185 & 0,0 \\
\hline Governo chinês & 3 & 0,400 & 0,0 \\
\hline BNDES & 2 & 0,157 & 0,0 \\
\hline Tesouro municipal & 2 & 2,100 & 2,100 \\
\hline Vários (privado) & 2 & 0,719 & 0,0 \\
\hline Vários (público) & 2 & 0,370 & 0,0 \\
\hline Total & 681 & 191,420 & 28,128 \\
\hline
\end{tabular}

Fonte: Cosiplan (2016, p. 29). Tradução nossa.

Assim, conforme os dados da tabela demonstram, de todos os valores estimados e executados como fonte de financiamento confirmados até agosto de 2016, o maior montante era oriundo dos tesouros nacionais dos países-membros da Unasul (US\$ 72,368 bilhões), seguido pelo investimento privado (US\$ 48,728 bilhões). Dentre as instituições financeiras, o maior investimento foi destinado pelo BID (US\$ 4,629 bilhões), seguido do CAF (US\$2,855 bilhões) e pelo FOCEM (US\$ 819 milhões). Quanto ao BNDES, o investimento total estimado para os projetos da IIRSA/Cosiplan até agosto de 2016 (US\$ 157,1 milhões), era menor do que 0,1\% de todos os investimentos estimados para a iniciativa. De fato, a contribuição estimada do BNDES era menor do que o investimento esperado do governo chinês (US\$400,0 milhões), do Japan Bank for International Cooperation (JBIC) (US\$ 185,9 milhões), e da União Europeia (US\$179,5 milhões). 
Desta forma, é possível afirmar que não houve participação massiva do BNDES nos financiamentos das obras da IIRSA, nem existiu um protagonismo ou antagonismo significativo do banco nos projetos da iniciativa (COSTA, 2011). Além disso, de acordo com o coordenador nacional Ernesto Carrara Junior, "o BNDES financia os projetos que the são apresentados por empresas brasileiras estando estas na linha de frente de ação" (HONÓRIO, 2013, p. 104). Outra questão importante que merece ser lembrada é que algumas construtoras brasileiras também atuam na região por meio dos créditos obtidos em outras instituições, como o CAF (WEXELL SEVERO, 2015).

Outro ponto abordado por Wexell Severo (2015), que tem relevância para o estudo, é que, de modo geral, os capitais brasileiros não são os maiores em nenhum dos países vizinhos e representam uma proporção muito pequena dos investimentos brasileiros no exterior, mesmo com o crescimento da presença de grandes empresas brasileiras no Uruguai, Paraguai e na Argentina. Na Tabela 3, esses números podem ser observados.

Tabela 3 - Origem do IED em países da América do Sul - Fluxos entre 2006-2013

\begin{tabular}{|c|c|c|c|c|c|}
\hline & $1^{\mathrm{a}}$ posição & $2^{a}$ posição & $3^{a}$ posição & $4^{a}$ posição & $5^{a}$ posição \\
\hline Argentina & EUA $(15,5 \%)$ & Espanha $(10,6 \%)$ & Holanda $(10,5 \%)$ & Brasil $(8,8 \%)$ & Chile $(8,5 \%)$ \\
\hline Bolívia & Espanha (33\%) & Suécia (17\%) & Inglaterra $(15 \%)$ & França (11\%) & Peru $(7,8 \%)$ \\
\hline Brasil & Holanda $(16,1 \%)$ & EUA $(15,6 \%)$ & Espanha $(7,2 \%)$ & Luxemburgo (6,9\%) & França $(6,4 \%)$ \\
\hline Chile & EUA $(16,7 \%)$ & \begin{tabular}{|l|} 
Holanda $(14,8 \%)$ \\
\end{tabular} & \begin{tabular}{|l|} 
Espanha $(10,4 \%)$ \\
\end{tabular} & Canadá $(5,1 \%)$ & Inglaterra $(4,3 \%)$ \\
\hline Colômbia & EUA (22\%) & Panamá $(14,7 \%)$ & Inglaterra $(12,1 \%)$ & Anguilla $(6,9 \%)$ & Espanha $(6,8 \%)$ \\
\hline Equador & México $(36,9 \%)$ & Panamá $(14,6 \%)$ & Brasil $(13,6 \%)$ & China $(12,8 \%)$ & Espanha (12,4\%) \\
\hline Paraguai & $\operatorname{EUA}(46,2 \%)$ & Brasil $(20,6 \%)$ & Argentina $(13,6 \%)$ & Espanha (5\%) & Panamá (5\%) \\
\hline Peru & Espanha $(20,2 \%)$ & Inglaterra (20\%) & EUA $(14,4 \%)$ & Holanda (7\%) & Chile $(6,1 \%)$ \\
\hline Uruguai & Argentina $(28,1 \%)$ & Espanha $(6,9 \%)$ & Brasil $(6,4 \%)$ & $\operatorname{EUA}(4,3 \%)$ & Inglaterra $(2,8 \%)$ \\
\hline Venezuela & Holanda $(17,4 \%)$ & EUA $(15,8 \%)$ & França $(7,2 \%)$ & Espanha $(5,6 \%)$ & Suíça $(4,8)$ \\
\hline
\end{tabular}

Fontes: Bancos Centrais ou órgãos estatais dos países

Fonte: Wexell Severo (2015, p. 257)

Entre os anos 2007 e 2013, o investimento estrangeiro acumulado do Brasil na região ficou em apenas $6,3 \%$ do total de investimentos brasileiros no exterior, sendo que os dois países da região que receberam maiores 
investimentos totais acumulados no período, Argentina e Uruguai, responderam por apenas 2,4\% e 1,4\% do total (WEXELL SEVERO, 2015, p. 259-260). Esses dados podem ser observados na Tabela 4 a seguir.

Tabela 4 - Estoque de Investimento Brasileiro Direto no mundo

Distribuição por país da empresa investida imediata (Banco Central do Brasil)

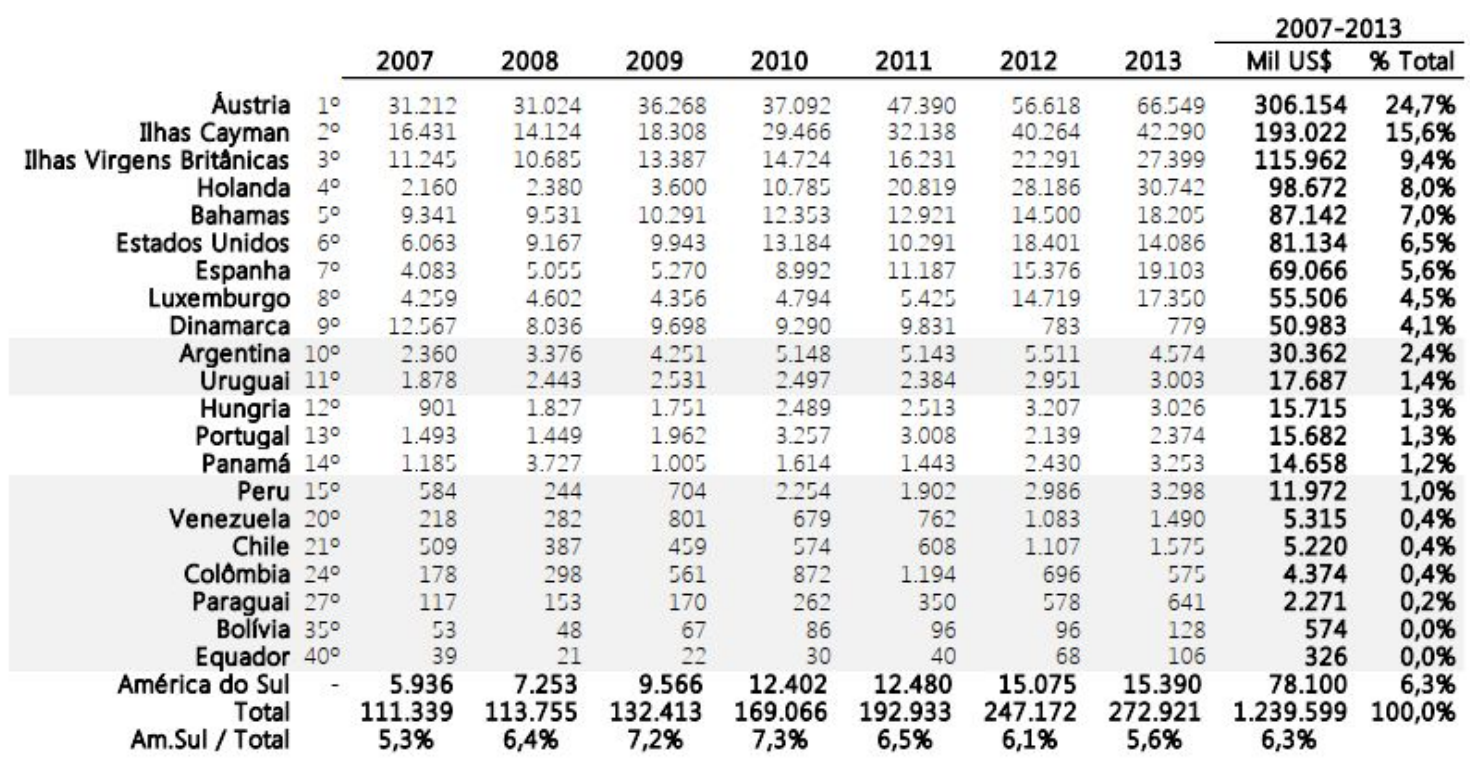

Fonte: Wexell Severo (2015, p. 260).

Estes dados corroboram com a deslegitimação da tese de que o Brasil estaria assumindo uma postura subimperialista, visto que em termos relativos os investimentos brasileiros na América do Sul são muito reduzidos. Ademais, as críticas sobre a participação do BNDES no financiamento das obras da IIRSA/Cosiplan são ambíguas. Cobrava-se, internacionalmente, que o Brasil adotasse a postura de paymaster das obras e, por outro lado, acusava-se o país de se utilizar do banco com intenções hegemônicas na América do Sul (HONÓRIO, 2013; WEXELL SEVERO, 2015).

Por fim, com relação ao papel de liderança que o Brasil buscou desempenhar nos processos de integração de infraestrutura regional, importaria analisar também os obstáculos à consolidação dessa liderança. Sobre isso Wexell Severo (2015) aponta três principais desafios ou preocupações para a liderança brasileira do processo de integração: uma relacionada aos esforços externos, e mesmo internos, para desacreditar a 
liderança regional brasileira, apresentando o país como uma ameaça aos vizinhos; outra diz respeito às tentativas de desestabilizar a parceria estratégica entre Brasil e Argentina - considerada o núcleo duro da integração sul-americana; e, finalmente, a destacada participação norte-americana nas dinâmicas regional.

\section{CONSIDERAÇÕES FINAIS}

A partir do exposto, considera-se que o conceito de subimperialismo elaborado por Marini nos anos 1970, um período histórico muito distinto ao período de criação da IIRSA, apresenta limitações teóricas à análise da participação brasileira nos processos de integração em infraestrutura na América do Sul, possuindo pouca aplicabilidade quando analisado para o período demarcado nesta pesquisa.

Apesar do fato das empresas brasileiras de construção civil terem sido beneficiadas, e do superávit na balança comercial brasileira com seus vizinhos ter crescido (LUCE, 2007), a tese do subimperialismo brasileiro expresso através dos investimentos brasileiros na IIRSA/Cosiplan, não se comprova. Os investimentos do Brasil realizados através do BNDES são inexpressivos, menos de $0,1 \%$ do total de investimentos na Carteira de Projetos do Cosiplan até 2016. À frente dos investimentos brasileiros estão os investimentos de países como China e Japão, além dos investimentos da União Europeia (COSIPLAN, 2016).

Em contrapartida, havia uma pressão política dos próprios governos da região para que o Brasil desempenhasse o papel de principal financiador das obras da iniciativa. Ademais, a participação dos capitais brasileiros nas economias dos países da região é pouco expressiva, uma vez que o Brasil não está entre os maiores investidores de nenhum país sul-americano, apesar da presença de suas empresas no Paraguai, Argentina e Uruguai, principalmente. 
O projeto da IIRSA/Cosiplan foi consolidado em um período em que a América do Sul foi priorizada pela política externa brasileira. Assim, o país buscou interconectar-se mais com seu entorno geográfico e estratégico e ter influência nas tomadas de decisões, intensificando o diálogo conjunto, almejando alcançar melhores níveis de desenvolvimento econômico e social, de autonomia política, de estabilidade e de segurança para o Brasil e para a região, devido ao reconhecimento da interdependência entre os países sul-americanos e do potencial da região em tornar-se um polo de poder mundial. Os incentivos dados à integração, com a formação da IIRSA e da Unasul, demonstram essas intenções.

Ademais, os investimentos brasileiros cumpriam parte central da estratégia adotada pelo país para incentivar e promover a integração, seguindo o princípio de que os países com maiores recursos deveriam oferecer as maiores contribuições financeiras. Sem a contribuição financeira brasileira, o discurso integracionista dos governos Lula e Dilma não encontraria sustentação. Portanto, ao invés de fazerem parte de uma prática subimperialista, os investimentos cumpriam o papel de respaldar a estratégia brasileira de integração sul-americana, visando alterar a inserção da América do Sul no sistema internacional através da integração da região.

Considera-se, desta forma, que a atuação brasileira pode ser melhor compreendida a partir do conceito de liderança regional ou potência regional emergente. Isso porque, apesar de a política externa brasileira estar voltada ao objetivo de consolidar o país como potência regional na América do Sul e o país apresentar as capacidades para isso, o Estado brasileiro não cumpriu, na prática, todos os requisitos para ser uma potência regional, apesar de exercer a liderança regional por um breve período. Por exemplo, fica evidente que o Brasil apresentou dificuldades para priorizar os investimentos na América do Sul, uma vez que os investimentos brasileiros na IIRSA/Cosiplan deveriam ser mais expressivos para que o país assumisse o posto de potência regional. Além disso, apesar 
de ser a maior potência militar da região, o Brasil ainda possui uma lacuna dentre as capacidades necessárias para defender a região de ameaças externas, o que implica custos (políticos, econômicos e militares) significativos.

Por fim, vale ressaltar que, apesar de todos os avanços na institucionalização regional alcançados nos anos 2000, percebe-se a paralisação ou retrocesso de muitas destas conquistas nos últimos anos. Esta conjuntura adversa à integração demonstra a dificuldade de se manter uma política pró-integração regional contínua no tempo e de longa duração, por parte de um Estado Nacional que, embora fosse considerado em certos períodos uma potência regional, ou potência emergente, não logrou consolidar o consenso nacional mínimo necessário para sustentar uma Grande Estratégia nacional para sua região geopolítica. Assim, muitos dos projetos de cooperação e integração e dos projetos de liderança regional e de Brasil enquanto potência regional emergente foram paralisados, regrediram ou, até mesmo, estão sendo desmantelados.

\section{REFERÊNCIAS}

AMORIM, Celso L. A integração sul-americana. Revista Diplomacia, Estratégia, Política. Brasília, n. 10, p. 9-21, out-dez.2009. Disponível em: <http://www.funag.gov.br/ipri/images/pdf/Revista_DEP10_Portugues.pdf>. Acesso em: 28 mai.2020.

AMORIM, Celso L. A Grande Estratégia do Brasil: discursos, artigos e entrevista da gestão no Ministério da Defesa (2011-2014). Antonio Jorge Ramalho da Rocha et al (ed.). Brasília: FUNAG, 2016. Disponível em: <http://funag.gov.br/biblioteca/download/1145-A-Grande-Estrategia-do-Bra sil_FINAL_25_04.pdf>.Acesso em: 30 mai.2020.

ANDRADE, Carolina Borges. Subimperialismo brasileiro na perspectiva da integração da infraestrutura regional sul-americana. Monografia (Graduação em Ciências Econômicas) - Universidade Federal de Santa Catarina, UFSC, Florianópolis, 2015. Disponível em <https://repositorio.ufsc.br/xmlui/handle/123456789/134829>. Acesso em 06 ago. 2020. 
ARRIGHI, Giovanni. O longo século XX: dinheiro, poder e as origens do nosso tempo. Rio de Janeiro: Contraponto, 2006.

BID. Conheça o BID. Banco Interamericano de Desenvolvimento, 06 ago. 2020. Disponível em: <https://www.iadb.org/pt/sobre-o-bid/visao-geral>. Acesso em: 06 ago. 2020.

BRAGA, Jorge Luiz Raposo. O BNDES e o projeto de integração regional: internacionalização de empresas brasileiras no jogo político da América do Sul. Encuentro de Geógrafos de América Latina. Lima, Peru, 2013, p. 1-21.

CAF. Quem somos. Banco de Desenvolvimento da América Latina, 06 ago. 2020. Disponível em: <https://www.caf.com/pt/sobre-a-caf/quem-somos/>. Acesso em: 06 ago. 2020.

CARVALHO, Patrícia Nasser de; GONÇALVES, Fernanda Cristina Nanci Izidro. O Brasil como potência regional: uma análise da sua liderança na América do Sul no início do século XXI. Carta Internacional. Belo Horizonte, v. $11, \quad$ n. 3, p. 222-248, 2016. Disponível em: <https://doi.org/10.21530/ci.v11n3.2016.570>. Acesso em: 07 ago. 2020.

CASTRO, Edna. Expansão da fronteira, megaprojetos de infraestrutura e integração sul-americana. Caderno CRH. Salvador, v. 25, n. 64, p. 45-61, jan./abr., $2012 . \quad$ Disponível em: <https://doi.org/10.1590/S0103-49792012000100004>. Acesso em: 28 mai. 2020.

CECEÑA, Ana Esther. Os caminhos e os agentes do saqueio da América Latina. In: Empresas Transnacionais brasileiras na América Latina: um debate necessário. São Paulo: Editora Expressão Popular, 2009, p. 205-218.

CERVO, Amado Luiz. Inserção internacional: formação de conceitos brasileiros. Saraiva, São Paulo, 2008.

COMUNICADO DE BRASÍlIA. Reunião de Presidentes da América do Sul. Iniciativa para a Integração da Infraestrutura Regional Sul-Americana. Brasília, DF, 01 set. 2000. Disponível em: <https://www.oei.es/historico/oeivirt/cimeiral.htm>. Acesso em: 31 mai. 2020.

COSIPLAN. Cartera de Proyectos 2016. Venezuela, dez.2016. Disponível em: <http://www.iirsa.org/admin_iirsa_web/Uploads/Documents/Cartera\%20201 6_web.pdf>. Acesso em: 06 ago. 2020.

COSTA, Darc A. (Org.). América do Sul: integração e infraestrutura, um estudo sobre temas e projetos essenciais para a integração regional, como energia e transportes. Rio de Janeiro: CapaxDei, 2011.

COSTA, Wanderley Messias. Geografia política e geopolítica: discursos sobre o território e o poder. 2.ed, São Paulo: Editora USP, 2008 
FIORI, José Luís. O sistema mundial, no início do século XXI. In: FIORI, José Luis; SERRANO, Franklin; MEDEIROS, Carlos. O mito do colapso americano. Rio de Janeiro: Editora Record, 2008.

FIORI, José Luís. Brasil e América do Sul: o desafio da inserção internacional soberana. Textos para Discussão CEPAL-IPEA, 42. CEPAL. Escritório no Brasil/IPEA. Brasília, DF, 2011.

FLEMES, Daniel; SARAIVA, Miriam Gomes. Potências emergentes na ordem de redes: o caso do Brasil. Revista Brasileira de Política Internacional. Brasília, v. 57, n. 2, jul./dez. 2014. Disponível em: <http://dx.doi.org/10.1590/0034-7329201400312>. Acesso em: 05 ago. 2020.

FONPLATA. Missão e visão. Fundo Financeiro para Desenvolvimento da Bacia do Prata, 06 ago. $2020 . \quad$ Disponível em: <https://www.fonplata.org/pt/institucional/missao-e-visao>. Acesso em: 06 ago. 2020.

FONTES, Virgínia. O imperialismo brasileiro. In: Empresas Transnacionais brasileiras na América Latina: um debate necessário. São Paulo: Editora Expressão Popular, 2009, p. 219- 245.

GRASSI, Jéssica Maria. Geopolítica de Brasil e Argentina: percepções sobre a América do Sul e as relações bilaterais. Revista Neiba - Cadernos Brasil-Argentina. v. 8, n. 1, p. 1-25, 2019a. Disponível em: <https://doi.org/10.12957/neiba.2019.47837>. Acesso em: 27 mai. 2020.

GRASSI, Jéssica Maria. Parceria Estratégica entre Brasil e Argentina: cooperação nuclear e integração sul-americana no século $X X I$. Dissertação (Mestrado em Integração Contemporânea da América Latina) Universidade Federal da Integração Latino-Americana, UNILA, Foz do Iguaçu, 2019b. Disponível em: <http://dspace.unila.edu.br/123456789/4916>. Acesso em: 27 mai. 2020.

GRATIUS, Susanne. Brasil en las Américas: ¿Una potencia regional pacificadora?. Fundación para las Relaciones Internacionales y el Diálogo Exterior (FRIDE). Documento de Trabajo 35, abril, Madrid, 2007.

GUIMARÃES, Samuel Pinheiro. O mundo multipolar e a integração sul-americana. Temas \& Matizes, Cascavel, 2008, n. 14, p. 58-72. Disponível em:

<http://e-revista.unioeste.br/index.php/temasematizes/article/view/2484>. Acesso em: 06 ago. 2020.

HONÓRIO, Karen Santos. O significado da iniciativa para a integração da infraestrutura regional sul-americana (IIRSA) no regionalismo sul-americano (2000-2012): um estudo sobre a iniciativa e a participação do Brasil. Dissertação (Mestrado em Relações Internacionais) UNESP/UNICAMP/PUC-SP, São 2013. <http://hdl.handle.net/11449/128074>. Acesso em: 27 mai. 2020. 
JAEGER, Bruna Coelho. A integração infraestrutural sul-americana: impactos sobre a estratégia e a geopolítica regional. Monografia (Graduação em Relações Internacionais) - Universidade Federal do Rio Grande do Sul, UFRGS, Porto Alegre, 2014. Disponível em: <http://hdl.handle.net/10183/116365>. Acesso em: 27 mai. 2020.

JAEGER, Bruna Coelho. Debatendo o conceito de "Subimperialismo" à época da ditadura civil-militar (1964-1985) e do Governo Lula da Silva (2003-2010). Mediações - Revista de Ciências Sociais, Dossiê Interpretações do Brasil Contemporâneo, v. 23, n. 2, mai./ago., 2018. Disponível em: <10.5433/2176-6665.2018.2v23n2p224>. Acesso em: 05 ago. 2020.

KERR OLIVEIRA, Lucas et al. Análise de estruturas geopolíticas e de tendências de aumento da competição interestatal internacional: contribuições para a prospecção de cenários de ameaças à Soberania Brasileira sobre o Pré-Sal. Revista Brasileira de Estudos de Defesa, v. 3, nº 2, p. 139-176, jul./dez. 2016. Disponível em <https://doi.org/10.26792/rbed.v3n2.2016.72306>. Acesso em: 31 mai. 2020.

KERR OLIVEIRA, Lucas; MARQUES, Teresa Cristina Schneider. A Infraestrutura da Integração Regional e a Integração Brasil-Uruguai. In: MALLMANN, Maria Izabel, MARQUES, Teresa Cristina Schneider (Orgs.). Fronteiras e relações Brasil-Uruguai.. Porto Alegre: EDIPUCRS, 2015, p. 109-126.

LÊNIN, Vladimir. O imperialismo, fase superior do capitalismo. Lisboa-Moscou: Editorial Progresso, 1916.

LIMA, Maria Regina Soares. Relações interamericanas: a nova agenda sul-americana e o Brasil. Lua Nova. São Paulo, n. 90, p. 167-201, 2013. Disponível em: <https://www.scielo.br/pdf/In/n90/a07n90.pdf>. Acesso em: 27 mai. 2020.

LIMA, Rafael Teixeira. A integração regional em infraestrutura da IIRSA e os capitais do BNDES nos governos Lula da Silva (2003-2010): Subimperialismo do neodesenvolvimentismo brasileiro? Dissertação (Mestrado em Integração Contemporânea da América Latina), Universidade Federal da Integração Latino-Americana, UNILA, Foz do Iguaçu, 2018. Disponível em: <http://dspace.unila.edu.br/123456789/3641>. Acesso em: 06 ago. 2020.

LUCE, Mathias Seibel. O subimperialismo brasileiro revisitado: a política de integração regional do governo Lula (2003-2007). Dissertação (Mestrado em Relações Internacionais) - Universidade Federal do Rio Grande do Sul, UFRGS, Porto Alegre, 2007. Disponível em: <http://hdl.handle.net/10183/14394>. Acesso em: 27 mai. 2020.

MARINI, Ruy Mauro. Subdesarrollo y revolución. Siglo XXI Editores, 5 ed., México, 1974. 
MARINI, Ruy Mauro. La acumulación capitalista mundial y el subimperialismo. Cuadernos Políticos. México, n. 12, abr./jun., 1977. Disponível <http://www.olafinanciera.unam.mx/new_web/10/pdfs/Marini-Clasicos-OlaF in-10.pdf>. Acesso em: 26 mai. 2020.

MEARSHEIMER, John. A Tragédia da Política das Grandes Potências. Lisboa: Gradiva, 2007.

MINISTÉRIO DO PLANEJAMENTO. Sobre o PAC. Disponível em: < http://pac.gov.br/sobre-o-pac >. Acesso em 30 set.2020.

MONIZ BANDEIRA, Luiz Alberto. O Brasil como potência regional e a importância estratégica da América do Sul na sua política exterior. Temas \& Matizes, Dossiê: Mercosul: Lutas Populares e Projetos Sociais, v. 7, n. 14, p. 09-32, jul./dez. 2008. Disponível em: <http://e-revista.unioeste.br/index.php/temasematizes/article/view/2477>. Acesso em: 29 mai. 2020.

MORAIS SILVA, Ana Karolina; KERR OLIVEIRA, Lucas. Desenvolvimento, soberania e geopolítica: o papel da integração de infraestrutura energética na América do Sul. Revista Brasileira de Iniciação Científica, v. 6, p. 65-82, 2019 <https://periodicos.itp.ifsp.edu.br/index.php/IC/article/view/1540>. Acesso em: 31 mai. 2020.

NOLTE, Detlef. How to compare regional powers: analytical concepts and research topics. Review of International Studies. Cambridge, v. 36, p. 881-901, 2010. Disponível em: <https://www.giga-hamburg.de/sites/default/files/publications/how_to_co mpare.pdf>. Acesso em: 27 mai. 2020.

NYE Jr., Joseph. Cooperação e conflito nas Relações Internacionais. São Paulo: Editora Gente, 2009.

PADULA, Raphael. Integração regional de infraestrutura e comércio na América do Sul nos anos 2000: uma análise político-estratégica. Tese (Doutorado em Engenharia de Produção) - Universidade Federal do Rio de Janeiro, UFRJ, Rio de Janeiro, 2010. Disponível em: <http://objdig.ufrj.br/60/teses/coppe_d/RaphaelPadula.pdf>. Acesso em: 29 mai. 2020.

PAZ, Gabrielle Santos. Integração da América do Sul: o BNDES como agente da política regional do governo Lula. Anais do $\mathbf{1}^{\circ}$ Seminário Internacional de Ciência Política: Estado e Democracia em mudança no século XXI. UFRGS, Porto Alegre, 09-11 set.2015. Disponível em: <https://www.ufrgs.br/sicp/wp-content/uploads/2015/09/PAZ-2015-Integra\% C3\%A7\%C3\%A3o-da-Am\%C3\%A9rica-do-Sul.pdf>. Acesso em: 29 mai. 2020. 
PECEQUILO, Cristina Soreanu. As relações Brasil-Estados Unidos. Belo Horizonte: Fino Traço, 2011.

SARAIVA, Miriam Gomes. Encontros e Desencontros: o lugar da Argentina na política externa brasileira. Belo Horizonte: Fino Traço, 2012.

SEABRA, Raphael. L. Do dependentismo à teoria marxista da dependência: uma síntese crítica desta transição. Revista Sociedade e Estado, v. 34, n. 1, jan./abr., $2019 . \quad$ Disponível em: <https://www.scielo.br/pdf/se/v34n1/0102-6992-se-34-01-261.pdf>. Acesso em: 06 ago. 2020.

SENHORAS, Elói Martins. Regionalismo transnacional e integração física: um estudo sobre a iniciativa de integração da infraestrutura sul-americana. Dissertação (Mestrado em Geografia) - Universidade Estadual de Campinas, Unicamp, Campinas, 2008. Disponível em: <http://repositorio.unicamp.br/jspui/handle/REPOSIP/287269>. Acesso em 07 mai. 2020.

SENNES, Ricardo. Brasil na América do Sul: internacionalização da economia, acordos seletivos e estratégia hub-and-spokes. IPEA. Revista Tempo do Mundo. Rio de Janeiro, v. 2, n. 3, dez., 2010. Disponível em: <http://www.ipea.gov.br/revistas/index.php/rtm/article/view/115>.

SPEKTOR, Matias. Ideias de ativismo regional: a transformação das leituras brasileiras da região. Revista Brasileira de Política Internacional. Brasília, v. 53, n.1, p. 25-44, 2010. Disponível em: <https://doi.org/10.1590/S0034-73292010000100002>. Acesso em: 27 mai. 2020.

VISENTINI, Paulo G. Fagundes. O Brasil, o Mercosul e a integração na América do Sul. p. 93-129. In: Wiesebron, M.; Griffiths, M. (Orgs.). Processos de Integração regional e cooperação intercontinental desde 1989. Porto Alegre: Editora UFRGS, 2008.

WEXELL SEVERO, Luciano. Integração econômica e desenvolvimento da América do Sul: o Brasil e a desconstrução das assimetrias regionais. Tese (Doutorado em Economia Política Internacional) - Universidade Federal do Rio de Janeiro, UFRJ, Rio de Janeiro, 2015. 


\section{APÊNDICE}

Quadro 1 - Síntese dos conceitos apresentados para a análise da atuação brasileira na América do Sul

\begin{tabular}{|c|c|}
\hline Conceito & Definição resumida e variáveis para análise \\
\hline $\begin{array}{c}\text { Subimperialismo } \\
\text { (MARINI, } \\
\text { 1974 e 1977). }\end{array}$ & $\begin{array}{l}\text { - Economia dependente que alcançou etapa dos monopólios e do } \\
\text { capital financeiro; } \\
\text { - Política expansionista relativamente autônoma, mas subordinada à } \\
\text { potência imperialista; } \\
\text { - Incorporação de mercados já formados, atendendo aos interesses } \\
\text { da burguesia industrial; } \\
\text { - Integração de capital nacional ao capital estrangeiro; } \\
\text { - Divórcio entre as fases do ciclo de capital; } \\
\text { - Superexploração do trabalho; } \\
\text { - Monopolização extrema em favor da indústria suntuária. }\end{array}$ \\
\hline $\begin{array}{c}\text { Potência } \\
\text { Regional } \\
\text { (NOLTE, 2O10) } \\
\text { (GRATIUS, 2007) } \\
\text { (MONIZ } \\
\text { BANDEIRA, 2008) }\end{array}$ & $\begin{array}{l}\text { - Articula a pretensão de liderança em uma região econômica, } \\
\text { política e ideacionalmente delimitada; } \\
\text { - Dispõe dos recursos materiais (militar, econômico, demográfico), } \\
\text { organizacionais (políticos) e ideológicos para projetar seu poder } \\
\text { regionalmente; } \\
\text { - Deve ser econômica, política e culturalmente interconectado com } \\
\text { a região; } \\
\text { - Tem influência na delimitação geopolítica e na construção política, } \\
\text { econômica e geoestratégica da região, com papel importante na } \\
\text { definição da agenda de segurança; } \\
\text { - Exerce influência nas estruturas de governança regional; } \\
\text { - Se compromete com os processos de integração regional; } \\
\text {-Tem influência na definição e articulação da identidade e no projeto } \\
\text { comum da região; } \\
\text { - Proporciona e se esforça pelo bem coletivo; } \\
\text { - Sua liderança é respeitada e reconhecida pelos demais; } \\
\text { - Integra fóruns e instituições inter-regionais e globais, } \\
\text { representando também a região em fóruns internacionais. }\end{array}$ \\
\hline $\begin{array}{c}\text { Liderança } \\
\text { Regional } \\
\text { (PADULA, 2010) } \\
\text { (FIORI, 2011) } \\
\text { (LIMA, 2013) } \\
\text { (KERR OLIVEIRA } \\
\text { et al, 2016). }\end{array}$ & $\begin{array}{l}\text { - Coordenação estreita entre as agências responsáveis pela política } \\
\text { externa do país; } \\
\text { - Vontade estratégica consistente e permanente; } \\
\text { - Capacidade social e estatal de construir consensos; } \\
\text { - Capacidade de planejar e implementar ações conjuntas; } \\
\text { - Capacidade de influenciar os resultados, e não de influenciar a } \\
\text { terceiros; } \\
\text { - PIB e população são indicadores importantes para mediar a } \\
\text { capacidade de liderança; } \\
\text { - Importância da capacidade de proteger ou defender o processo de } \\
\text { integração regional de ameaças externas; } \\
\text { - Uso planejado de meios de pagamento, do favorecimento do } \\
\text { comércio e do desenvolvimento dos vizinhos, da redução das } \\
\text { assimetrias, do financiamento de obras para a integração e da } \\
\text { distribuição de outros bens públicos de uso comum à região; } \\
\text { - Pode ser uma liderança expansiva (concentrando ganhos políticos } \\
\text { e econômicos no líder em detrimento do desempenho político e }\end{array}$ \\
\hline
\end{tabular}


econômico dos demais países);

- Pode se desenvolver de modo que a expansão do líder favoreça a expansão econômica e política dos demais países, não combatendo assimetrias pré-existentes;

- Pode ser uma liderança em que a expansão do líder favoreça a expansão econômica e política dos demais países e do conjunto, combatendo em parte as assimetrias, mas que ainda garanta a posição privilegiada do líder;

- Ou ainda, uma liderança cooperativa, na qual a expansão do líder proporciona ganhos políticos e econômicos recíprocos ao conjunto de países, reduzindo as assimetrias pré-existentes, na medida do possível.

Fonte: elaborado pelos autores a partir da revisão bibliográfica exposta no artigo. 